Saudi Journal of Humanities and Social Sciences

Abbreviated Key Title: Saudi J Humanities Soc Sci

ISSN 2415-6256 (Print) | ISSN 2415-6248 (Online)

Scholars Middle East Publishers, Dubai, United Arab Emirates

Journal homepage: https://saudijournals.com/sjhss

Original Research Article

\title{
Distribution of Provincial and Regency/City Authorities in Management of Coastal Sea Areas
}

\author{
Khelda Ayunita $^{1 *}$, Achmad Ruslan², Abd Razak², Hamzah Halim² \\ ${ }^{1}$ Doctoral Student, Faculty of Law, Hasanuddin University, Indonesia \\ ${ }^{2}$ Professor, Faculty of Law, Hasanuddin University, Indonesia
}

DOI: $10.36348 /$ sjhss.2020.v05i04.003 $\quad$ | Received: 30.03 .2020 | Accepted: 08.04.2020 | Published: 14.04 .2020

*Corresponding author: Khelda Ayunita

Abstract

The purpose of this study was to the authority of the provincial government in the management of coastal sea areas, and the authority of regency/city governments in the management of coastal sea areas. This type of research is normative legal research, using a conceptual approach and a statute approach. The legal materials used in this study consist of primary, secondary and tertiary legal materials. The legal material that has been described in accordance with the main problem is then distributed, explored and then given an argument so that the whole forms a logically interconnected whole about the disclosure of logical rationale and the ontological basis for the issuance of laws governing coastal marine areas. The results of this study indicate that the regulation of management of marine resources is still centralized so that there are many conflicts with the authority of the Regional Government. The promulgation of Law 23 Year 2014 concerning Regional Government whose authority to manage sea areas is the Provincial Region. This article has aborted Article 18 paragraph (1) of Law 32 Year 2004 which states that Regions that have sea territories are given the authority to process resources in their sea territories. The impact of local governments is the difficulty to guarantee the welfare and/or prosperity of the people in this case the people in the sea area which lead to injustice in realizing the people's constitutional rights.

Keywords: Coastal sea area, distribution on of authority, management.

Copyright @ 2020: This is an open-access article distributed under the terms of the Creative Commons Attribution license which permits unrestricted use, distribution, and reproduction in any medium for non-commercial use (NonCommercial, or CC-BY-NC) provided the original author and source are credited.

\section{INTRODUCTION}

The state is the main actor in the fulfillment of the rights of its citizens, including the fulfillment of a sense of security from crime and social conflict [1]. International treaties should bring good for every country that makes them [2]. The history of local governance in Indonesia, decentralization and centralization have shifted several times. There are many factors that influence the ups and downs of decentralization, especially the nature of state power (central government) whether moving in a democratic or authoritarian direction. However, the shift that occurred must of course remain in the corridor of the 1945 Constitution of the Republic of Indonesia as the highest law. According to the concept of a unitary state decentralization comes from centralization. However, on the other hand decentralization and regional autonomy are provisions of the 1945 Constitution of the Republic of Indonesia.
This means that the unitary state must be run in tandem with regional autonomy. Centralization must not eliminate the existence of regional autonomy as constitutional mandate. In Law Number 23 Year 2014 concerning Regional Government, there is a tendency towards centralization. These trends can be identified both in terms of the concept of the distribution of functions, the authority to form regional regulations, as well as in the distribution of authority, especially for the management of natural resources, forestry, and mining[3]. The preamble of Law No. 23 Year 2014 states that the efficiency and effectiveness of the administration of regional government need to be improved by paying more attention to aspects of the relationship between the central and regional governments and regions, the potential and diversity of the region, as well as the opportunities and challenges of global competition in the unity of the state governance system. 
Legislation as a legal product becomes a very important tool in the implementation of state life [4]. The issuance of Law No. 23 Year 2014 has an impact on autonomy in the management of coastal and small islands. Article 27 of Law No. 23 Year 2014. Management of marine resources fully under the authority of the provincial area.

Article 27 paragraph (1) of Law No. 23 Year 2014 revokes the authority of regencies/cities in the management of marine resources. The authority of a provincial region to manage resources in a sea area no more than 12 (twelve) nautical miles is measured from the base line towards the open sea and/or towards archipelagic waters (Article 27 paragraph (3) of Law 23 Year 2014). This article strengthens the granting of authority to the Provincial Government, where previously there was the authority of the Regency/City Government as far as 4 (four) nautical miles as stipulated in Article 18 paragraph (4) of Law 32 Year 2004, which states that the authority to manage resources in the sea area is as referred to in paragraph (3) a maximum of 12 (twelve) nautical miles measured from the coastline towards the high seas and/or towards archipelagic waters for the province and $1 / 3$ (one third) of the province's jurisdiction for regencies/cities.

In the case of the division of affairs between the Central Government, the Provincial Region and the Regency/City Region specifically in the maritime and fisheries sector which is regulated by law there is no granting of management authority to the Regency/City Region which is taken over by the Central Government and the provincial region. There is an assumption that the granting of authority only to the Provincial Government of the Region is not in accordance with the purpose of granting the broadest possible autonomy to the Regions which is directed to accelerate the realization of people's welfare through service improvement, empowerment, and community participation. Moreover, an important substance of regional autonomy is the transfer of authority from the center to the regions politically and economically so that development and economic growth take place fairly and evenly in the regions.

Many other problems can arise when almost all regional affairs are handled by the Central Government. Examples in the case of coastal databases and small islands whose authority is exercised by the Central Government which can actually be submitted to the Regency/City Government whose territory will be collected. On the other hand, the unequal distribution of authority can reduce the Regional Budget Revenue (Pendapatan Asli Daerah/PAD) and also when there are problems in the regions related to various policies that are handled by the Central Government, the handling must all be done by the Central Government.
Interests oriented to political power and strengthening regional assets are problems that often arise in the implementation of regional autonomy. These interests are also affected by damage to the environment (ecology), population growth (demographics), fewer jobs (livelihoods), the political environment, changes in technology and changes in the level of commercialization (markets) which at some level causes conflict.

In marine management in the regions in this study, the emphasis is on adjusting regulations related to sea management with Law Number 23 Year 2014. Equitable development and welfare improvement have not been achieved in Indonesia, even today. Concerns that the potential of the region is being shut down, and that the Regency/City losing capital important for its development needs attention and study. Therefore, an appropriate pattern of relationship and distribution of authority between the Central and Regional Governments is needed in order to avoid the phenomenon or bad access due to unequal relations and division of authority between the Center and the Regions..

Thus, based on Article 27 paragraph (3) of Law 23 Year 2014, starting from the coastline to 12 nautical miles is the authority of the Provincial Government. Meanwhile, the provincial government, which has the character of the island, has received an abundance of authority from the central government. This is as stipulated in article 28 paragraph (2) of Law 23 Year 2014, that in addition to exercising authority to manage resources in the sea area, for provinces that are characterized by islands, the central government assigns the exercise of its authority in the maritime sector. Assignments can only be carried out if the provincial government which is characterized by the archipelago meets the norms, standards, procedures and criteria set by the central government.

In the case of maritime and fisheries management, there are reasons why the region must remain involved in its management, this is because the region does not only accept and carry out provincial and central policies because the one that has a place/area of management is the Regency/City Government.

The approach to withdrawing all power/authority is partial centralization or micro centralization which in reality alienates the community from regional authorities (bureaucracy) who are supposed to deal with problems in the region. The paradox about this distance will cause inefficiency and obstacles to public participation and oversight of the government[5]. 
When compared to Law Number 23 Year 2014 with Law Number 1 Year 2014 concerning Amendments to Law Number 27 Year 2007 concerning Management of Coastal Areas and Small Islands (PWP \& PPK Law), between Law Number 23 Year 2014 and PWP \& PPK Law has Significant difference, the PWP $\&$ PPK Law has the spirit to give authority to the regions (provinces and regencies/cities) to manage coastal and small islands comprehensively. The authority delegated from planning, utilization (including licensing), conservation and protection, monitoring and evaluation, research and development to community empowerment[6].

Anxiety about the negative impact caused by Law Number 32 Year 2004 concerning Regional Government, has caused the strengthening of status to the Provincial Government's position as an extension of the Central power as an autonomous region through Law No. 23 Year 2014 by withdrawing functions that have been handled by the Government Regency/City Regions on the grounds that the governor fails to prevent abuse of power from Regency/City Governments and especially in mining, maritime and forestry issues, and also on the grounds of the negative impact of such abuse of power which causes severe environmental damage due to the exploitation of Regional Governments Regency/City in the context of increasing their regional income.

Based on the description above, the ratification of Law Number 23 Year 2014 addresses the problem, namely since the enactment of Law Number 23 Year 2014 concerning Regional Governments where authority is withdrawn to the provinces. Management of conservation areas, capture fisheries, permits and supervision as well as spatial planning are under the authority of the Provincial government with a very wide area of management covering 18 districts with an area of $94,399.85 \mathrm{~km}^{2}$. The impact of the community is increasingly far from maritime sector service access because they have to go to the Province. The practice of Illegal flute fishing is handled with limited supervision from the province as well as other bureaucratic obstacles. As many as $75 \%$ of the area of South Sulawesi is coastal and marine, which is rich in fisheries resources and high biodiversity which if optimized its governance can encourage local independence and community welfare. The ability of the South Sulawesi Provincial Government to manage the permits of hundreds of fishing vessels in the coastal area is one of the very serious issues. From the perspective of public services, this will certainly have a huge impact on fishing vessel licensing services. Communities who will take care of permits must go to the provincial office, how far the distance must be taken and the costs to be incurred as well as the time required to obtain a fishing permit. This is certainly contrary to the principles of good public service and does not reflect the objectives of decentralization, because one of the main objectives in the implementation of decentralization is to give the public easier access to the services needed. In this perspective the author sees that Law Number 23 Year 2014 does not consider aspects of convenience in public service delivery. This can be seen by not considering the geographical aspects, access and variety of stakeholders who need services related to fishing vessel licensing. Furthermore, another problem that will arise is how to implement adequate governance of Monitoring Controlling and Surveillance (MCS) while the Province still has to deal with technical and administrative issues such as the number and capacity of human resources (HR), the number of Technical Implementing Units (Unit Pengelola Teknis/UPT) Povinsi in the regency/city area and limited infrastructure. While on the other hand, the area of fisheries management has become larger. So that the reformulation of fisheries governance under this regional government law regime needs to be formulated.

Good management of resources is bringing managers (government) closer to the community or resources. Not the other way around, pulling the authority to manage marine resources to the provincial level which is very far from the coastal regencies/cities. The unclear division of authority between the Provincial Government and Regency/City Governments in the management of coastal resources and small islands due to the PWP \& PPK Law is still valid and there are no implementing regulations for Law Number 23 Year 2014 related to the authority to manage coastal areas and small islands, resulting in uncertainty. law in the management of coastal areas and small islands. Equitable development and welfare improvement have not been achieved in Indonesia, even today. Concerns about the potential of the region being turned off, and regencies/cities losing capital important to their development need attention and study. Therefore, an appropriate pattern of relationship and distribution of authority between the Central and Regional Governments is needed in order to avoid the phenomenon or bad access due to unequal relations and division of authority between the Center and the Regions in the management of marine resources.

When referring to Law No. 23 Year 2014, maritime affairs are the authority of the provincial government as stipulated in Article 12 paragraph (3) point (a) "Provincial government has the authority to manage its marine potential up to 12 miles". Furthermore, the authority of the provincial region at sea in accordance with Article 27 of Law No. 23 Year 2014, namely that the provincial region is given the authority to manage natural resources at sea in its territory. As is known that the fishing community base is located in coastal areas in the Regency/City. The enactment of Law No. 23 Year 2014 has an impact on the difficulties of local governments to guarantee the welfare and/or prosperity of the people in this case the 
people in the sea area in particular and all the people of Indonesia which results in injustice in realizing the people's constitutional rights. Based on this, there is a phenomenon of imbalance between the Provincial Government and Regency/City Governments in the management of coastal sea areas due to the management of coastal sea areas where there is still a disproportionate tug of authority between Provinces and Regencies/Cities that causes tensions that lead to conflicts of authority.

Enactment of Law No. 23 Year 2014 concerning Regional Government has an impact on the loss of authority of the Regency/City Government for maritime and fisheries affairs so that it affects the configuration and structure of institutions, personnel, public services, finance and guidance and supervision. In addition, legal uncertainty arises due to the validity of regulations and legislation in the field of maritime affairs and fisheries that are contradictory to Law No. 23 Year 2014. The reality that occurs with the enactment of Law No.23 of 2014 is the supervision and spatial planning of South Sulawesi Province. with a very wide area of management covering 18 districts with an area of $94,399.85 \mathrm{~km}$. As a result, people are increasingly far from maritime sector service access because they have to go to the Province. The practice of illegal fishing is difficult to deal with with limited supervision from Provinsin and other bureaucratic obstacles besides, the ability of the Provincial Government to manage the licensing of hundreds of thousands of fishing vessels in its region is one of the very serious issues. Based on the explanation, the problem that will be discussed in this paper is what is the authority of the provincial government in the management of coastal marine areas? and how is the authority of the regency/city government in management the coastal sea area?

\section{RESEARCH METHOD}

This type of research is a normative legal research, using a conceptual approach and a statute approach[7].The legal materials used in this study consist of primary, secondary and tertiary legal materials[8].The legal material that has been described in accordance with the main problem is then distributed, explored and then given an argument so that the whole forms a logically interconnected whole concerning the disclosure of logical rationale and ontological basis for the issuance of laws governing the management of the coastal marine area and the laws of the local government governing management of coastal marine areas. Analysis of the data used is qualitative[9].

\section{DISCUSSION}

\section{The Authority of the Provincial Government in the} Management of Coastal Marine Areas

Indonesia is also a scattered archipelago in the world consisting of around $17,508^{2}$ islands with a sea area of around 5.8 million $\mathrm{km}^{2}$ and a line stretch of
$81,000 \mathrm{~km}^{2}$. Most of the islands are small islands that have a wealth of natural resources and environmental services that are very potential for economic development[10]. Sea is one of the sources of wealth of a country, because it saves natural resources very much, be it fish, seaweed, rocks, coral, and others. One of the lucky countries by the grace of the god associated with the marine area is Indonesia [11].

In the development of coastal and coastal areas the Provincial Government is a subsystem in national development. This means that the development of the area is an inseparable part of and at the same time integrated with national development, the implementation of which refers to the guiding law method, and is the development of and for the community carried out by the community together with the government, in all aspects of community life. in a planned, gradual and sustainable manner, in accordance with the conditions, potential and aspirations of the people who are growing and developing in the region or region.

The authority given to the provincial government shows that the management of fish resources is still running in a centralized spirit. Space for public participation in decision making related to fish management is not found in the Fisheries Law. Likewise, protection of the rights of indigenous peoples. There is not a single article in this Law that mentions indigenous peoples and their rights to the control and management of fish resources.

With the enactment of Law Number 23 Year 2014, delegation of governmental authority is left to the Province. In line with this principle, the principle of autonomy in natural resources is in the hands of the Province in a real and responsible manner. The principle of real autonomy is a principle that for and handling governmental affairs in the Province is carried out based on the duties, authorities and obligations that actually already exist and have the potential to grow, live and develop in accordance with the potential and specificity of the region. What is meant by responsible autonomy is Provincial-based autonomy which in its implementation must be truly in line with the purpose and purpose of granting autonomy, which is basically to empower the regions including improving people's welfare which is a major part of national goals.

Specifically relating to the authority to manage sea areas, Law Number 23 Year 2014 is based on the Province:

1. Regency/City no longer has a sea area given the authority to manage resources in the sea area.

2. Regency/City obtains profit sharing on the management of natural resources under the sea floor and / or based on the laws and regulations.

3. Regency/City no longer has the authority to manage resources in the sea area: 
a) exploration, exploitation, conservation and management of marine resources;

b) administrative arrangements;

c) spatial planning;

d) law enforcement of regulations issued by regions or that delegate authority by the government;

e) participate in security maintenance; and

f) participate in the defense of State sovereignty.

4. Regency/City does not have the authority to manage resources in the sea area and the Province has the authority of 12 (twelve) nautical miles measured from the coastline towards the high seas and/or towards archipelagic waters for the Province and $1 / 3$ (one third) from the province's jurisdiction to the Regency/City.

Thus the Provincial Government has a very important role in utilizing all existing potentials to fill national development in general and in particular regional development towards the welfare of the people of the various potential marine resources they have. Especially for people who inhabit coastal areas.

Previous legislation (Law Number 32 Year 2004) is more oriented towards the exploitation of Regency/City-level coastal resources without regard to resource sustainability. Meanwhile, awareness of the strategic value of sustainable coastal management in an integrated, community-based way is relatively lacking. In addition, Law Number 32 of 2004 lacks the respect of the rights of customary/local communities in the management of coastal resources, as well as limited space for community participation, especially coastal communities in the management of marine resources, but Law Number 23 Year 2014 is accommodating even though based on Province and Regency/City as the executor.

A.M. Yunus Wahid declare value which is a study of philosophical value (axiology) which is usually used to designate "abstract nouns" which can be interpreted as worth or goodness[12]. The rule of law (supremacy of law) is supremacy of juctice as well as vice versa, both are commutative things. The law is not in the absolute dimension of the law, but the law is in the dimension of absolute justice [13]. To carry out regency/city government authority in the field of management and utilization in the sector of coastal areas and small islands handed over to the central government and the provincial government so that resulting in organizing the affairs of the regency/city government in terms of management and utilization in the coastal and island sector small islands changed which had been decentralized and after the enactment of Law 23 Year 2014 changed to deconcentration set by the central government on the management and utilization of coastal areas and small islands. Based on the attachment of the division of maritime and fisheries affairs in Law 23 of 2014, the regency/city area no longer deals with the management of coastal areas and small islands. The Authority of the Regency/City Government in the Management of Coastal Marine Areas

Indonesian foreign policy and diplomacy are carried out to ensure the guarantee of Indonesia's national interests, national development goals, economic growth, people's welfare, democratic consolidation and the achievement of social justice for all Indonesian people [14]. After the enactment of Law Number 23 Year 2014 concerning regional government which has been running for 4 years, the authority of sea management which has been managed by the regency/city government has been transferred to the provincial authority. This law, among others, regulates the expansion of the authority of the Province i maritime and fisheries sector. If the Province's authority was originally from 4-12 miles and the Regency/City's authority amounted to 0-4 miles, now the Provincial Government's authority has been expanded from 0 to 12 miles so that the authority of the Regency/City's Government is removed. This policy certainly has an impact on the supervision system and public services amid the limited number of state civil servants in the Provincial Government. The exercise of the authority of the Provincial Region, the sea mentioned in Article 27 paragraph (2) conveys the authority of the Provincial Region to manage natural resources in the sea. In addition, the authority to administer the Province of the Sea is regulated at most 12 nautical miles measured from the coastline towards the high seas and or direction of archipelago waters.

With the enactment of Law No. 23 Year 2014 concerning Regional Government, there is a change in the authority to manage resources in coastal sea areas for Regencies/Cities. This effort is intended so that the administration of government is much cleaner, more effective, efficient, accountable, and optimal. However, the implication is that there are obstacles in particular in the discussion of the authority of the regency/city government in matters of the field of coastal marine affairs and small islands. Because the authority to manage marine resources will only be more in the Provincial government. and in the attachment to Law No. 23 Year 2014 concerning Regional Governments concerning the division of concurrent governmental affairs between the central, provincial, and Regency/City governments are not given authority over the sub-division of affairs concerning marine, coastal and small island management. However, in Article 50 paragraph (3) of Law Number 1 Year 2014 concerning Amendments to Law Number 27 Year 2007 concerning Management of Coastal Sea Areas and Small Islands Regents/Mayors have the right to grant licenses and revoke licenses for management of coastal marine areas. and small islands. This directly means giving 
authority to the Regency/City to manage the sea, coast and small islands (coastal waters).

In addition, with the enactment of Law No. 23 Year 2014, causing technical agencies namely the Office which used to be in accordance with the nomenclature named Marine and Fisheries, in the Regency/City area finally dropped into the status of the Fisheries Service. Marine, Coastal and Small Islands, Processing and marketing and Oversight are eliminated because they relate to the authority of the Province in marine management. In addition, the issuance of permits for large fishing vessels until the size of 0-30 GT has all become the authority of the Provincial Maritime and Fisheries Service, SIUP, SIPI/SIKPI and BPKP. The Regency/City Fisheries Office only deals with fish auction sites, empowering small fishermen and small-scale fish farming which certainly has an impact on the Regional Original Revenue.

Regency/City has a fishing community but does not have the authority to manage the sea is something that looks irrelevant to the spirit of regional autonomy. The Provincial Government which should be an extension of the central government in the region only coordinates each policy that will be implemented in the Regency/City area.

Some coastal areas in Indonesia have quite high potential and strategic fishing areas so that inevitably the main livelihood for the people who live mainly in coastal areas is by fishing[15]. Located in the world coral triangle area, the Indonesian sea is rich in a variety of marine biota such as fish and coral reefs. Not surprisingly, Indonesia is one of the largest fish producers in the world, including for reef fish species. As a strategic commodity, reef fishing is one of the most cultivated by our fishermen [16]. Fishermen who live in coastal areas and are administratively registered as residents of the Regency/City if carrying out activities in the vicinity of the coast and the sea, must now be in contact with technical agencies namely the Provincial Marine and Fisheries Service such as for fishing, conservation and supervision activities. Fishermen hope that the policy can return to normal, namely technical agencies in the Regency/City can provide services according to their authority, as before so that it is more efficient and makes it easier for fishermen to operate coastal and sea activities.

\section{CONCLUSION}

The regulation of management of marine resources is still centralized so that there are many conflicts with the authority of the Regional Government. The promulgation of Law 23 Year 2014 concerning Regional Government whose authority to manage sea areas is the Provincial Region. This article has aborted Article 18 paragraph (1) of Law 32 Year 2004 which states that Regions that have sea territories are given the authority to process resources in their sea territories. The impact of local governments is the difficulty to guarantee the welfare and/or prosperity of the people in this case the people in the sea area which lead to injustice in realizing the people's constitutional rights.

\section{REFERENCES}

1. Birkah, L., \& Kadarudin. (2012). Pengantar Hukum Internasional (Introduction to International Law), Makassar: Pustaka Pena Press, 39

2. Birkah, L., \& Kadarudin. (2012). Hukum Perjanjian Internasional (International Treaty Law), Makassar: Pustaka Pena Press, 51

3. Muhammad Ali Safa'at, Sentralisasi dalam UU Nomor 23 Tahun 2014 tentang Pemerintahan Daerah (Centralization in Law Number 23 Year 2014 concerning Regional Government), delivered at the focus group discussion "Inventory Issues Law No.23 of 2014 concerning Regional Government" organized by the Association of Regency Governments throughout Indonesia (Asosiasi Pemerintah Kabupaten seluruh Indonesia/APKASI). Jakarta, 15 September 2015.

4. Achmad, R. (2011). Peraturan PerundangUndangan Sebagai Sarana Hukum Penyelenggaraan Negara (Legislation as a Means of State Administration), Professor's Oration, 6

5. http:/www.thejakartapost.com/news/2014/12/22/ov ercoming-problems-new-autonomy-era.html accessed on February 122019.

6. Rikardo, S., \& Asep, Y.F. (2016). Pemberlakuan UU No. 23 Tahun 2014 dan Desentralisasi di Bidang Pengelolaan Sumber Daya Alam (Enactment of Law no. 23 of 2014 and Decentralization in the Field of Natural Resource Management), Association for Community-Based and Ecological Legal Reform (Perkumpulan untuk Pembaharuan Hukum Berbasis Masyarakat dan Ekologis/HUMA), Jakarta, 2016, 30

7. Peter, M.M. (2003). Penelitian Hukum (Legal Reaearch), Prenada Media, Jakarta.

8. Roni, H. S. (1998). Metodologi Penelitian Hukum dan Jurimetri (Legal and Jurimetry Research Methodology), Penerbit Ghalia Indonesia Jakarta, 125

9. Kadarudin, K., Thamrin, H., \& Liao, Y. M. (2018, August). Drug- Related Crimes and Control in Indonesia and Taiwan: Cooperation Regarding Narcotics Smuggling Prevention and Countermeasures from the Point of View of International Law. In International Conference on Knowledge Management in Organizations (pp. 312-323). Springer, Cham.

10. Patittingi, F. (2012). Dimensi hukum pulau-pulau kecil di Indonesia: studi atas penguasaan dan pemilikan tanah. Rangkang Education.

11. Asis, A. Slamet, S. S., \& Ilyas, A. (2016). Strategic policy of the government of Indonesia In the field of maritime and fisheries affairs. International 
Journal of Scientific and Research Publications, 6, 238-43.

12. Wahid, A.M.Y., (2011). Aktualisasi Kearifan Lokal Menuju Hukum Lingkungan Yang Responsif, Makassar: Pustaka Pena Press

13. Aburaera, S. (2010). Filsafat Hukum Dari Rekuntruksi Sabda Manusia Dan Pegetahuan Hingga Keadilan Dan Kebenaran. Makassar: Pustaka Refleksi.

14. Kadarudin, K., Thamrin, H., Liao, I. M., \& Satalak, P. (2019). Mutual Benefit Principle As Bilateral Basis of Indonesia With Thailand And
Taiwan. International Journal of Global Community, 2(1-March), 33-52.

15. Abd, A. (2016). Hak-Kewajiban Nelayan dan Kelompok Nelayan Menurut UU RI Nomor 7 Tahun 2016 (Rights and Obligations of Fishermen and Fishermen Groups According to Law No. 7 Year 2016), Jurnal Hukum “Justitia”, 5(1),53

16. Asis, A., Sampurno, S., Ilyas, A., Indrawati, D., \& Muin, A. M. (2018). Persoalan hukum nelayan dan kelompok nelayan di kabupaten takalar. The Juris, 2(2), 175-186. 